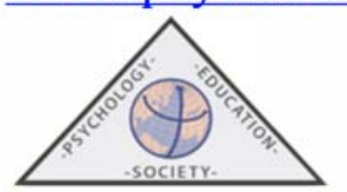

\title{
Preschool Teachers' Engagement in Professional Development: Frequency, Perceived Usefulness, and Relationship with Self-Efficacy Beliefs
}

\author{
David MÚÑEZ, Alfredo BAUTISTA, Ellyn KHIU, Jun-Sheng KEH \& Rebecca BULL \\ National Institute of Education. Education \& Cognitive Development Laboratory, Nanyang \\ Technological University (Singapore)
}

(Received on January 20, 2017; Accepted on February 19, 2017)

\begin{abstract}
Enhancing the quality of early childhood education is currently a central goal for many countries. There is widespread agreement that providing preschool teachers with opportunities for professional development (PD) is one of the key ingredients to achieving such a goal. Little is known, however, about the frequency with which preschool teachers engage in the different types of PD activities and about how teachers themselves perceive the usefulness of these activities. Similarly, there is limited research on how participating in PD relates to teachers' self-efficacy beliefs. The present study addresses these gaps in the literature with data collected in a Southeast Asian country: Singapore. Participants were 97 Singapore preschool teachers. A survey composing of several scales was used to collect the data. We explored the frequency and perceived usefulness of seven formal PD activities and 19 informal PD activities, both collaborative and individual. Teachers' self-efficacy was measured with the 'Teacher Sense of Efficacy Scale' (TSES). Our findings showed that: 1) Participants engaged in informal PD (both collaborative and individual) more frequently than in formal PD; 2) There were positive correlations between frequency of participation and teachers' perceived usefulness for both formal and informal PD; and 3) High engagement in collaborative informal PD activities was a strong predictor of teachers' self-efficacy beliefs. These results indicate that work-embedded PD, both collaborative and individual, is highly important to Singapore preschool teachers. In order to enhance the impact and responsiveness of PD, we suggest that formal PD should be integrated as part of the informal PD activities in which teachers regularly engage. Limitations and lines for further research are discussed.
\end{abstract}

Keywords: Preschool Education, Teacher Professional Development, Self-Efficacy Beliefs, Singapore 
Participación en Desarrollo Profesional de Maestros de Educación Infantil: Frecuencia, Utilidad Percibida y Relaciones con las Creencias de Autoeficacia

RESUMEN: Mejorar la calidad de la educación infantil es una meta central en muchos países actualmente. Existe un acuerdo generalizado en que ofrecer oportunidades de desarrollo profesional docente (DPD) a los maestros/as es uno de los ingredientes principales para lograr dicho objetivo. Sin embargo, poco se sabe sobre la frecuencia con la que estos profesionales participan en iniciativas de DPD o sobre sus percepciones acerca de la utilidad de dichas iniciativas. Existe también poca investigación sobre las relaciones entre la participación en DPD y las creencias de auto-eficacia de estos profesionales. El presente estudio aborda estos vacíos en la literatura desde la perspectiva de un país del Sudeste Asiático: Singapur. Los participantes fueron 97 maestras de escuelas infantiles. Para recoger los datos, utilizamos una encuesta compuesta por varias escalas estandarizadas. Exploramos la frecuencia y la utilidad percibida de siete actividades de DPD formal y de 19 informal, tanto colectivas como individuales. Las creencias de auto-eficacia fueron analizadas mediante la escala 'Teacher Sense of Efficacy Scale' (TSES). Los resultados muestran que: 1) Las maestras participaban en actividades informales de DPD (tanto colaborativas como individuales) más frecuentemente que en iniciativas formales; 2) Encontramos correlaciones positivas entre la frecuencia de participación en DPD y su utilidad percibida, tanto del DPD formal como informal; 3) Alta participación en actividades colaborativas informales predice alto sentido de auto-eficacia. Estos resultados indican que el DPD que tiene lugar en la escuela, tanto colaborativo como individual, resulta crucial para las maestras de infantil en Singapur. Para mejorar el impacto y la relevancia del DPD, sugerimos que el DPD formal debería integrarse como parte de las actividades informales en las que los profesores participan cotidianamente. Se discuten las limitaciones y futuras líneas de investigación.

Palabras Clave: Educación Infantil, Desarrollo Profesional Docente, Creencias de AutoEficacia, Singapur

\section{Acknowledgements}

This study was funded by the Education Research Funding Programme, National Institute of Education (NIE), Nanyang Technological University, Singapore, project OER 09/14RB. 'Singapore Kindergarten Impact Project' (SKIP). The views expressed in this paper are the author's and do not necessarily represent the views of NIE.

Correspondence: Dr Alfredo Bautista, Research Scientist \& Lecturer. Nanyang Technological University - National Institute of Education. Education and Cognitive Development Laboratory. 1 Nanyang Walk. NIE5-B3-16. Singapore [637616]. Phone: (+65) 6790 3208. Fax: (+65) 6896 9845. Email: Alfredo.Bautista@nie.edu.sg 


\section{INTRODUCTION}

In recent years, nations and international organizations around the world have put in place numerous measures to enhance the quality of early childhood education ${ }^{1}$ (ECE), a sector that is widely diverse both within and across countries. One of these measures has been providing inservice preschool teachers with opportunities to foster their learning and professional development (PD). It is typically assumed that both formal (e.g., seminars, courses, programs) and informal PD learning experiences (e.g., collaborative reflection, discussion groups) are relevant to promote the professional growth of these teachers, and in turn benefit the learning and development of children (Bautista \& Ortega-Ruíz, 2015). However, little research has investigated the actual frequency with which preschool teachers engage in different types of PD and the perceived usefulness of these activities. Moreover, little is known about the extent to which preschool teachers' participation in PD contributes to their self-efficacy beliefs as teaching professionals. The present study addresses these gaps in the literature from the perspective of a Southeast Asian country: Singapore.

\section{Enhancing the quality of the ECE sector through formal and informal PD}

Scholars have typically categorized PD under two broad types, namely formal and informal (Richter, Kunter, Klusmann, Lüdtke, \& Baumert, 2011).Formal PD, also referred to as 'traditional' by some scholars, tend to follow a specified curriculum. These are commonly delivered in structured learning environments by external PD providers, outside of the work place, and are often mandatory. Examples of these activities are structured seminars and workshops, graduate courses and programs, or mandated staff development conferences and symposiums (Bautista, Cañadas, Brizuela, \& Schliemann, 2015). Most formal PD utilizes faceto-face instruction, being therefore constrained to a specific time period and location, which inherently possess both temporal and geographic difficulties for teachers (Jones \& Dexter, 2014). Formal PD is also characterized by the common lack of follow-up support given to teachers after the completion of the event.

Informal PD activities, in contrast, are generally teacher-led and work-embedded, which allows teachers to reflect on their teaching practices and to learn from their fellow colleagues (Borko, 2004). Unlike formal PD, informal PD activities can be either planned or unplanned as well as structured or unstructured. In most cases, however, these activities do not follow a specified curriculum and are not constrained to specific learning environments or time periods (Jones \& Dexter, 2014). Informal PD is commonly optional (not mandatory), emerging from teachers' own initiatives (Eraut, 2004). Examples of informal PD include collaborative activities (e.g., peer-observation, mentoring and coaching, teacher networks, professional learning communities, communities of practice, action research, study groups) as well as individual activities (e.g., reading books, searching the Internet, experimenting with new techniques in the classroom) (Lohman, 2009). The literature has shown that informal PD has

\footnotetext{
${ }^{1}$ This field has been referred to using an array of different terms in the literature (e.g., early childhood development, childhood development, early childhood care and education, early care and education). In this article, we use "early childhood education' (ECE) as an inclusive term to refer to the comprehensive services offered to young children and their families prior to entry to formal school.
} 
the potential to lead to changes in teachers' behavior, cognition, emotions, and motivations (Hoekstra, Beijaard, Brekelmans, \& Korthagen, 2007). The flexibility and choice inherent in these types of PD activities are features that foster teachers' motivation to collaborate and improve themselves, either as a collective or individually (Schneider \& Kipp, 2015). The negative side, however, is that teachers oftentimes do not have sufficient organizational support (in terms of time, space, and resources) to engage in informal and individual PD.

The ECE literature has provided evidence that continuing training has strong positive effects on preschool teachers' pedagogical knowledge and skills, motivations, self-regulatory skills, personal development, cultural enrichment, and social relations with their fellow colleagues (Sheridan, Edwards, Marvin, \& Knoche, 2009). In addition, there is unanimous agreement on the positive effects that PD has on the quality of education received by children in the classroom (Wagner \& French, 2010). Finally, some research has suggested that continuing training also has positive effects on the labor market conditions of preschool teachers (e.g., employment opportunities, working mobility) (Pineda, Ucar, Moreno, \& Belvis, 2011).

In reviewing the preschool education literature, we found very few studies specifically looking at teachers' perceived usefulness of particular types of formal and informal PD activities. Moor et al. (2005) evaluated the effects of an intensive PD pilot scheme for preschool educators. The participants completed various PD activities that were spread over three years. By the end of the program, they reported that the scheme was useful as it allowed them to improve their teaching practices, contributed to enhance their pupils' learning as well as their own willingness to engage in further PD. Moor et al. (2005) analyzed the factors that influenced teachers' perceived usefulness of the PD scheme, finding that having autonomy in selecting the PD activities, the support of the school, and the help of experienced mentors were the most important predictors of teacher satisfaction. In addition, ECE research has suggested that the level of challenge, sense of community and belonging within the workplace, and the context in which PD is delivered influence preschool teachers' motivation and/or satisfaction with PD activities (Wagner \& French, 2010).

\section{Teacher PD and self-efficacy}

Little is known about the extent to which preschool teachers' participation in PD contributes to their self-efficacy beliefs as teaching professionals. The construct of TSE builds upon Bandura's (1977) assumption that individuals' behaviors are influenced by their perceived capabilities to perform such behaviors successfully. Mastery experiences, physiological and affective states, vicarious experiences provided by social models, and social persuasion contribute to the development of these beliefs (Bandura, 1977). In particular, TSE is typically conceptualized as including three dimensions, namely 1) classroom management, 2) students' engagement, and 3) instructional practices (Tschannen-Moran \& Hoy, 2001). Much has been written during the past decades about TSE, which today are regarded as key motivational beliefs influencing teachers' practices and student learning (e.g., Klassen, Tze, Betts, \& Gordon, 2011). Studies conducted in Western countries have suggested that preschool teachers tend to show high levels of TSE (Guo, Dynia, Pelatti, \& Justice, 2014).

The literature has suggested that preschool teachers who engage in PD activities tend to exhibit higher levels of self-efficacy. In particular, PD perceived to be closely aligned with 
teachers' own practice and with students' expected learning outcomes seems to have a higher impact on teachers' efficacy (Ingvarson, Meiers, \& Beavis, 2005). There is evidence supporting the impact of both formal (Duran, Ballone-Duran, Haney, \& Beltyukova, 2009) and informal PD activities (Rimm-Kaufman \& Sawyer, 2004). In a study conducted with preschool teachers in United States, Guo, Justice, Sawyer, and Tompkins (2011) examined how teacher and classroom characteristics predicted teachers' sense of efficacy. One of the findings was that teachers' collaboration with other fellow colleagues within informal settings was essential in fostering their self-efficacy. This finding supports the importance of encouraging collegial sharing among preschool educators (Epstein \& Willhite, 2015). Teachers' collaboration seems to be critically important, especially given the specific challenges associated to this profession (e.g., low salaries, lack of a clear career path, poor social recognition). Collaborating with other colleagues may contribute to mitigate these challenges by providing teachers with reinforcement and validation, and expanding their content and pedagogical knowledge (Ross \& Bruce, 2007).

\section{Context for the research: Singapore}

The present study was conducted in Singapore. The Singapore Government has implemented many efforts to improve the PD resources offered to preschool teachers. One of the most distinguished providers of PD is the Early Childhood Development Agency (ECDA), which strongly encourages all preschool teachers to participate in a minimum of 20 hours of PD per year. Both formal and informal (center-based) PD activities are recognized (ECDA, 2016). Since its establishment, ECDA has conducted a wide variety of formal PD initiatives - primarily courses and workshops - in collaboration with other training agencies such as SEED Institute and Science Centre Board. These PD initiatives have been varied with regards to content focus (e.g., child development, learning environments, curriculum design in the different learning areas), duration (from short and sporadic PD events to more extensive and intensive programs), and delivery style (including face-to-face and online initiatives).To a lesser extent, ECDA has also implemented initiatives focused on action research, mentoring and peer observation, and has led numerous formal cluster meetings. The 'Continuing Professional Development' (CPD) framework (ECDA, 2013) provides ECE personnel with structured pathways to develop and update their professional knowledge, skills, and dispositions, while customizing PD to the specific needs and progressive levels of competencies of each teacher. The preschools themselves can be considered as another provider of PD, as many professional learning activities in which teachers typically engage are embedded in the workplace. Indeed, ECDA also places much emphasis on informal modes of teacher PD (e.g., professional learning communities, networked learning, informal discussions, sharing of innovative pedagogies), which are deemed to both enhance teachers' content and pedagogical knowledge and bring about a sense of belonging, camaraderie, and solidarity among ECE educators.

\section{GOALS}

The first goal of this study was to explore Singapore preschool teachers' engagement in $\mathrm{PD}$, focusing on the frequency and perceived usefulness of specific types of formal and informal PD activities. Despite the wealth of PD resources available to Singapore teachers 
(Bautista, Wong, \& Gopinathan, 2015), no published research has reported on the frequency with which preschool teachers participate in the different types of formal and informal PD activities. Similarly, no research has focused on exploring how preschool teachers themselves perceive the usefulness of the PD activities in which they participate.

Our second goal was to investigate the extent to which the frequency of those PD activities relates to teachers' self-efficacy beliefs. Most studies looking at the relationships between PD and teachers' self-efficacy beliefs have been conducted in Western countries. Given the lack of research on the topic conducted within the Singapore context, we do not know whether PD has similar effects on self-efficacy beliefs of Singapore preschool teachers. In the same vein, we do not know what specific types of PD (formal and informal) might produce these positive effects on teachers' self-efficacy beliefs.

\section{METHOD}

\section{Participants}

This study was conducted with a sample of 97 in-service preschool teachers, all of whom taught 5-year-old children. They were all females, with an average age of 33.7 years $(\mathrm{SD}=$ 11.0), and an average of 6.6 years of teaching experience $(\mathrm{SD}=5.6)$. The majority described themselves as Chinese (42.3\%), followed by Malay (25.8\%), Indian (22.7 \%), and Filipino $(9.3 \%)$. All teachers hold some form of certification specific to early childhood education: 57 of them hold a diploma (58.8\%), 22 a bachelor's degree $(22.7 \%), 12$ a certificate $(12.4 \%)$, three a specialist diploma (3.1\%), and three were graduates with a master's degree $(3.1 \%)$.

\section{Procedure and measures}

Data for this study were collected at one time-point. Participants were asked to complete a survey composed of several standardized scales. The survey was distributed through Qualtrics $^{\mathrm{TM}}$. On average, teachers took 18 minutes to complete the full survey. The teachers gave informed consent and were informed that the data would be analyzed and reported anonymously.

The survey included a short demographic section, two items addressing the frequency and perceived usefulness of different types of PD activities previously completed by the teachers (both formal and informal), and five standardized scales that assessed teachers' job satisfaction, personality, beliefs about education, self-efficacy beliefs, and motivation. Below we describe the scales and items that are relevant to the two research questions of this paper.

\section{Demographic information}

In the demographic section, we asked the teachers to specify their age, gender, ethnicity, academic background, and years of teaching experience. The descriptive results have been presented in the Participants section.

\section{Frequency and perceived usefulness of prior $P D$}

We created two items to explore the frequency and perceived usefulness of the formal and informal PD activities previously completed by the preschool teachers. They were asked to indicate the number of times they had "participated in each of the activities presented during 
the past year" $(1=$ never; $2=1-3$ times; $3=4-6$ times; $4=$ more than 6 times $)$ and the degree of usefulness that the activity had had for them as preschool educators $(0=\mathrm{N} / \mathrm{A} ; 1=$ none, $2=$ small, 3 = moderate, $4=$ high). Note that the N/A answer was automatically assigned when the teacher had never participated in the specific activity at hand. The first item included seven types of formal PD (Table 1, left column), whereas the second item presented 19 types of informal PD (Table 1, right column).

\begin{tabular}{ll}
\hline \multicolumn{1}{c}{ Formal PD } \\
\hline 1. & $\begin{array}{l}\text { Short seminars, lectures, and/or workshops } \\
\text { (less than } 3 \text { hours) }\end{array}$ \\
2. & $\begin{array}{l}\text { Long seminars, lectures, and/or workshops } \\
\text { (more than } 3 \text { hours) }\end{array}$ \\
3. Conferences, symposiums or conventions \\
4. Individual or collaborative research on a \\
topic
\end{tabular}

\section{Informal PD}

Collective activities

1. Support colleagues in teaching problems

2. Talk about teaching problems with colleagues

3. Share ideas about educational improvement

4. Share way of teaching with colleagues

5. Share ideas about pupil counseling

6. Share ideas about education with colleagues

7. Make agreements about way of teaching

8. Receiving coaching of guidance

9. Coaching colleagues

10. Prepare lessons with colleagues

11. Use colleagues' materials in own lessons

Individual activities

12. Study subject matter literature

13. Read professional journals

14. Study teaching manuals

15. Preparing lessons individually

16. Experiment with new teaching methods

17. Construct lesson materials

18. Ask pupils' feedback

19. Adapt way of teaching to pupils' needs

Table 1. Formal and informalforms of PD included in the questionnaire

The list of formal PD activities was determined based on the courses and workshops currently provided by ECDA (2016), as described in the Introduction. The informal PD activities were adapted from Kwakman's (2003) work on teachers' informal learning. These involved four different types of learning processes (experimenting, reflecting, collaborating, and reading), which could be carried out either individually or in collaboration with preschool educators. Some of the activities reported by Kwakman (2003) were not included in our survey because they were thought of for higher education levels (e.g., Help students to learn study skills).

\section{Teachers' self-efficacy beliefs}

The 'Teacher Sense of Efficacy Scale' (TSES) (Tschannen-Moran \& Hoy, 2001) captures teachers' perceived level of efficacy and/or control over three aspects related to teaching practices, namely 1) instructional strategies (e.g., "How much can you use a variety of assessment strategies?"), 2) classroom management (e.g., "How much can you do to control disruptive behavior in the classroom?"), and 3) student engagement (e.g., "How much can you do to motivate students who show low interest in school?"). The TSES consists of 12 items 
(four items per subscale) and uses a 9-point likert-type scale with the following anchors: $1=$ Nothing, $3=$ Very Little, $5=$ Some Influence, $7=$ Quite a bit, and $9=$ A Great Deal. Overall consistency (Cronbach's alpha) for the instrument is .90, with alpha coefficients for each the three subscales ranging from .81to .86. For our sample of Singapore preschool teachers, overall consistency was .94 . Alpha coefficients for each subscale were: .87 for instructional strategies, .89 for classroom management, and .86 for student engagement.

\section{RESULTS}

\section{Teachers' Engagement in PD: Frequency and Perceived Usefulness}

Table 2 presents the descriptive results obtained regarding teachers' prior engagement in formal PD during the past year and its perceived usefulness. As shown, 'Seminars, lectures, and/or workshops', both short (less than 3 hours) and long (more than 3 hours), were among the most common types of formal activities, with more than $90 \%$ of the teachers having participated in this type of PD at least once over the past year. In contrast, less than $50 \%$ of the teachers had ever participated in activities such as 'Formal cluster meetings' (37.5\%), 'Individual or collaborative research on a topic' (43.7\%), or 'Online PD' (20.8\%). The category most frequently chosen to rate teachers' participation in formal PD was ' 1 to 3 times', whereas the percentage of teachers choosing the category 'More than 6' was typically the lowest.

Regarding perceived usefulness, we found that the perceived usefulness of formal PD activities was rated as 'Moderate' by at least $50 \%$ of the sample. The category 'Long seminars, lectures, and/or workshops (more than 3 hours)' with 37.5\%, obtained the largest percentage of teachers indicating 'High' usefulness. The categories 'Formal cluster meetings', 'Individual or collaborative research on a topic', and 'Online PD' had the largest percentage of teachers indicating 'Small' usefulness.

\begin{tabular}{|c|c|c|c|c|c|c|c|c|}
\hline & \multicolumn{4}{|c|}{ FREQUENCY } & \multicolumn{4}{|c|}{ USEFULNESS } \\
\hline & Never & $\begin{array}{c}1-3 \\
\text { times }\end{array}$ & $\begin{array}{c}4-6 \\
\text { times }\end{array}$ & $\begin{array}{l}\text { More } \\
\text { than } 6\end{array}$ & None & Small & Moderate & High \\
\hline $\begin{array}{l}\text { Short seminars, lectures, and/or } \\
\text { workshops (less than } 3 \text { hours) }\end{array}$ & $9.4 \%$ & $47.9 \%$ & $29.2 \%$ & $13.5 \%$ & $1.1 \%$ & $8.0 \%$ & $55.2 \%$ & $35.6 \%$ \\
\hline $\begin{array}{l}\text { Long seminars, lectures, and/or } \\
\text { workshops (more than } 3 \text { hours) }\end{array}$ & $16.7 \%$ & $47.9 \%$ & $26.0 \%$ & $9.4 \%$ & $0.0 \%$ & $6.3 \%$ & $56.3 \%$ & $37.5 \%$ \\
\hline $\begin{array}{l}\text { Conferences, symposiums or } \\
\text { conventions }\end{array}$ & $37.5 \%$ & $57.3 \%$ & $4.2 \%$ & $1.0 \%$ & $0.0 \%$ & $10.0 \%$ & $71.7 \%$ & $18.3 \%$ \\
\hline $\begin{array}{l}\text { Individual or collaborative } \\
\text { research on a topic }\end{array}$ & $57.3 \%$ & $30.2 \%$ & $7.3 \%$ & $5.2 \%$ & $0.0 \%$ & $7.3 \%$ & $61.0 \%$ & $31.7 \%$ \\
\hline Online PD & $79.2 \%$ & $16.7 \%$ & $2.1 \%$ & $2.1 \%$ & $5.0 \%$ & $20.0 \%$ & $50.0 \%$ & $25.0 \%$ \\
\hline Formal cluster meetings & $62.5 \%$ & $26.0 \%$ & $4.2 \%$ & $7.3 \%$ & $0.0 \%$ & $19.4 \%$ & $61.1 \%$ & $19.4 \%$ \\
\hline $\begin{array}{l}\text { Mentoring and/or peer } \\
\text { observation and coaching, as part } \\
\text { of a formal school initiative }\end{array}$ & $35.4 \%$ & $46.9 \%$ & $11.5 \%$ & $6.3 \%$ & $1.6 \%$ & $14.5 \%$ & $58.1 \%$ & $25.8 \%$ \\
\hline
\end{tabular}

Table 2: Formal PD activities.Percentage of teachers per rating (frequency and related usefulness). Weighted rates (100 percent, excluding N/A scores)

In contrast, many of the informal PD activities presented in the survey had been completed by nearly $100 \%$ of the teachers (Table 3 ). Similar to the formal PD, the category most frequently selected to indicate engagement in informal PD was '1-3 times', both for (C) Psy, Soc, \& Educ, 2017, Vol. 9(2) 
collective activities (e.g., 'Support colleagues in teaching problems') and individual activities (e.g., 'Study subject matter literature'). The percentage of teachers reporting frequency as 'More than 6 times' was the highest for four activities, also including both collective (e.g., 'Talk about teaching problems with colleagues') and individual activities (e.g., 'Construct lesson materials'). The teachers rated usefulness for most of the informal PD activities as 'Moderate', except for four activities that were rated as 'High' (these also included both collaborative and individual activities). The percentages of teachers who used the category 'None' regarding usefulness were low, ranging between $0 \%$ and $2.2 \%$. Recall that these figures were slightly higher for formal PD activities, ranging between $0 \%$ and $5 \%$.

\begin{tabular}{|c|c|c|c|c|c|c|c|c|}
\hline & \multicolumn{4}{|c|}{ FREQUENCY } & \multicolumn{4}{|c|}{ USEFULNESS } \\
\hline & Never & $\begin{array}{c}1-3 \\
\text { times }\end{array}$ & $\begin{array}{c}4-6 \\
\text { times }\end{array}$ & $\begin{array}{l}\text { More } \\
\text { than } 6\end{array}$ & None & Small & Moderate & High \\
\hline \multicolumn{9}{|l|}{ Collective activities } \\
\hline $\begin{array}{l}\text { Support colleagues in teaching } \\
\text { problems }\end{array}$ & $9.3 \%$ & $46.4 \%$ & $29.9 \%$ & $14.4 \%$ & $1.1 \%$ & $14.9 \%$ & $50.6 \%$ & $33.3 \%$ \\
\hline $\begin{array}{l}\text { Talk about teaching problems } \\
\text { with colleagues }\end{array}$ & $1.0 \%$ & $29.9 \%$ & $34.0 \%$ & $35.1 \%$ & $0.0 \%$ & $9.6 \%$ & $42.6 \%$ & $47.9 \%$ \\
\hline $\begin{array}{l}\text { Share ideas about educational } \\
\text { improvement }\end{array}$ & $0.0 \%$ & $36.1 \%$ & $29.9 \%$ & $34.0 \%$ & $1.0 \%$ & $5.2 \%$ & $49.5 \%$ & $44.3 \%$ \\
\hline $\begin{array}{l}\text { Share way of teaching with } \\
\text { colleagues }\end{array}$ & $1.0 \%$ & $40.2 \%$ & $32.0 \%$ & $26.8 \%$ & $0.0 \%$ & $8.3 \%$ & $52.1 \%$ & $39.6 \%$ \\
\hline $\begin{array}{l}\text { Share ideas about pupil } \\
\text { counseling }\end{array}$ & $14.4 \%$ & $38.1 \%$ & $28.9 \%$ & $18.6 \%$ & $0.0 \%$ & $12.0 \%$ & $51.8 \%$ & $36.1 \%$ \\
\hline $\begin{array}{l}\text { Share ideas about education } \\
\text { with colleagues }\end{array}$ & $8.2 \%$ & $37.1 \%$ & $32.0 \%$ & $22.7 \%$ & $0.0 \%$ & $10.1 \%$ & $53.9 \%$ & $36.0 \%$ \\
\hline $\begin{array}{l}\text { Make agreements about way } \\
\text { of teaching }\end{array}$ & $14.4 \%$ & $23.7 \%$ & $41.2 \%$ & $20.6 \%$ & $0.0 \%$ & $8.5 \%$ & $52.4 \%$ & $39.0 \%$ \\
\hline $\begin{array}{l}\text { Receiving coaching of } \\
\text { guidance }\end{array}$ & $5.2 \%$ & $55.7 \%$ & $24.7 \%$ & $14.4 \%$ & $2.2 \%$ & $12.1 \%$ & $51.6 \%$ & $34.1 \%$ \\
\hline Coaching colleagues & $23.7 \%$ & $47.4 \%$ & $18.6 \%$ & $10.3 \%$ & $1.4 \%$ & $18.9 \%$ & $54.1 \%$ & $25.7 \%$ \\
\hline $\begin{array}{l}\text { Prepare lessons with } \\
\text { colleagues }\end{array}$ & $14.4 \%$ & $27.8 \%$ & $30.9 \%$ & $26.8 \%$ & $0.0 \%$ & $6.0 \%$ & $51.8 \%$ & $42.2 \%$ \\
\hline $\begin{array}{l}\text { Use colleagues' materials in } \\
\text { own lessons }\end{array}$ & $15.5 \%$ & $56.7 \%$ & $18.6 \%$ & $9.3 \%$ & $0.0 \%$ & $14.6 \%$ & $56.1 \%$ & $29.3 \%$ \\
\hline \multicolumn{9}{|l|}{ Individual activities } \\
\hline Study subject matter literature & $28.9 \%$ & $46.4 \%$ & $17.5 \%$ & $7.2 \%$ & $1.5 \%$ & $17.9 \%$ & $64.2 \%$ & $16.4 \%$ \\
\hline Read professional journals & $24.7 \%$ & $52.6 \%$ & $12.4 \%$ & $10.3 \%$ & $0.0 \%$ & $14.1 \%$ & $64.8 \%$ & $21.1 \%$ \\
\hline Study teaching manuals & $15.5 \%$ & $50.5 \%$ & $15.5 \%$ & $18.6 \%$ & $0.0 \%$ & $12.3 \%$ & $58.0 \%$ & $29.6 \%$ \\
\hline Preparing lessons individually & $4.1 \%$ & $15.5 \%$ & $24.7 \%$ & $55.7 \%$ & $2.2 \%$ & $4.3 \%$ & $35.5 \%$ & $58.1 \%$ \\
\hline $\begin{array}{l}\text { Experiment with new teaching } \\
\text { methods }\end{array}$ & $3.1 \%$ & $29.9 \%$ & $39.2 \%$ & $27.8 \%$ & $2.1 \%$ & $5.3 \%$ & $50.0 \%$ & $42.6 \%$ \\
\hline Construct lesson materials & $1.0 \%$ & $16.5 \%$ & $26.8 \%$ & $55.7 \%$ & $0.0 \%$ & $5.3 \%$ & $37.9 \%$ & $56.8 \%$ \\
\hline Ask pupils’ feedback & $16.5 \%$ & $47.4 \%$ & $17.5 \%$ & $18.6 \%$ & $0.0 \%$ & $13.6 \%$ & $58.0 \%$ & $28.4 \%$ \\
\hline $\begin{array}{l}\text { Adapt way of teaching to } \\
\text { pupils' needs }\end{array}$ & $2.1 \%$ & $24.7 \%$ & $32.0 \%$ & $41.2 \%$ & $0.0 \%$ & $3.2 \%$ & $47.4 \%$ & $49.5 \%$ \\
\hline
\end{tabular}

Table 3: Informal learning activities. Percentage of teachers per rating (frequency and related usefulness)

We were interested to explore whether teachers' engagement in formal and informal PD differed. To do so, we performed an exploratory factor analysis. Our goal was to look for 
underlying constructs in the data related to the frequency of the different informal PD activities, which would yield a significant reduction in the number of items to be compared. We started by checking whether the data was suited for this kind of analysis. Then, we calculated the determinant of the correlation matrix in order to rule out extreme correlations between different variables, following the assumption of factor analysis that correlations among variables should be moderate. A Kaiser-Meyer-Olkin measure of sampling adequacy of 0.83 confirmed that the data was suitable for factor analysis. The analysis was performed using "listwise deletion" of missing scores and oblique rotation.

The factor analysis (Principal Component Analysis) revealed four different factors. Four items were not taken into account because either their loadings did not reach 0.45 or because they loaded similarly on several factors. The amount of variance accounted for by the four factors was $66.37 \%$. The first factor explained $37.20 \%$ and was named 'Collaborative Pedagogy Work'. The items that loaded on this factor concerned activities relating to children's education and involving the collaboration of several fellow colleagues. The second factor, which we named 'Individual Pedagogy Work', included three activities that dealt with teachers' self-direct (individual) acquisition of knowledge. This factor accounted for $11.19 \%$ of the explained variance. The third factor, 'Collaborative Lesson Planning', accounted for $7.73 \%$ and involved activities focused on designing and planning lesson materials and resources. Finally, the fourth factor, 'Individual Lesson Planning', concerned individual activities for lesson planning and explained $10.24 \%$ of the variance. Coefficients are shown in Table 4. Overall, these four factors distinguished the items according to two general dimensions. First, collaborative $v s$ individual PD activities. Second, general pedagogy work $v s$ lesson planning. Interestingly, despite the different number of factors, our results were in line with those of Kwakman (2003), who reported 'Collaborative Lesson Planning' and 'Individual Lesson Planning' as one single factor, namely 'Instructional Activities'.

\begin{tabular}{lcccc}
\hline & $\begin{array}{c}\text { Collaborative } \\
\text { Pedagogy } \\
\text { Work }\end{array}$ & $\begin{array}{c}\text { Individual } \\
\text { Pedagogy } \\
\text { Work }\end{array}$ & $\begin{array}{c}\text { Collaborative } \\
\text { Lesson } \\
\text { Planning }\end{array}$ & $\begin{array}{c}\text { Individual } \\
\text { Lesson } \\
\text { Planning }\end{array}$ \\
\hline Support colleagues in teaching problems & $\mathbf{0 . 6 3 2}$ & 0.420 & & \\
Talk about teaching problems with colleagues & $\mathbf{0 . 7 1 3}$ & & & 0.462 \\
Share ideas about educational improvement & $\mathbf{0 . 7 4 6}$ & & & \\
Share way of teaching with colleagues & $\mathbf{0 . 8 5 2}$ & & & \\
Share ideas about pupil counseling & $\mathbf{0 . 8 7 2}$ & & & \\
Share ideas about education with colleagues & $\mathbf{0 . 8 3 8}$ & & & \\
Study subject matter literature & & $\mathbf{0 . 7 6 7}$ & & \\
Read professional journals & & $\mathbf{0 . 7 9 6}$ & & \\
Study teaching manuals & & $\mathbf{0 . 7 3 9}$ & $\mathbf{0 . 7 4 3}$ & $\mathbf{0 . 4 8 2}$ \\
Use colleagues' materials in own lessons & 0.467 & & & $\mathbf{0 . 6 5 7}$ \\
Prepare lessons with colleagues & 0.563 & & & $\mathbf{0 . 8 2 7}$ \\
Adapt way of teaching to pupils' needs & & & & $\mathbf{0 . 8 3 0}$ \\
Preparing lessons individually & 0.412 & & \\
Experiment with new teaching methods & & & & \\
Construct lesson materials & & & & \\
\hline
\end{tabular}

Table 4.Factors loadings ( $>0.45)$ of items representing informal PD activities.

To explore teachers' ratings on frequency, a Friedman test was conducted to evaluate differences among types of formal PD activities and the four informal PD factors. The test (c) Psy, Soc, \& Educ, 2017, Vol. 9(2) 
indicated significant differences between frequency ratings for the different types of PD activities, $\chi^{2}(10, \mathrm{~N}=96)=430.87, p<.0001$. As shown in Table 5 , mean frequency ratings were higher for two out of four informal PD factors. Follow-up pairwise comparisons were conducted using a Wilcoxon test and controlling for the Type I errors across these comparisons at the .05 level, using the Bonferroni adjustment. The tests were conducted to evaluate whether mean frequency ratings for informal PD were statistically higher than those for formal PD. The analyses showed that the factors 'Individual Lesson Planning' and 'Collaborative Pedagogy Work' were significantly more frequent than any of the formal PD activities ( $p s<.05)$. No differences were found between these two factors. These results indicate that Singapore preschool teachers tend to participate in certain informal PD activities more frequently than in formal PD activities.

\begin{tabular}{lcc}
\hline & $\begin{array}{c}\text { Mean } \\
\text { (n=97) }\end{array}$ & $\begin{array}{c}\text { Standard } \\
\text { Deviation }\end{array}$ \\
\hline Formal learning activities & & .84 \\
$\quad$ Short seminars, lectures, and/or workshops (less than 3 hours) & 2.4 & .85 \\
Long seminars, lectures, and/or workshops (more than 3 hours) & 2.2 & .60 \\
Conferences, symposiums or conventions & 1.6 & .83 \\
Individual or collaborative research on a topic & 1.6 & .60 \\
Online PD & 1.2 & .88 \\
Formal cluster meetings & 1.5 & .84 \\
Mentoring and/or peer observation and coaching, as part of a formal & 1.8 & .69 \\
school initiative & & .70 \\
Informal learning factors & 2.7 & .78 \\
Collaborative Pedagogy Work & 2.1 & .63 \\
$\quad$ Individual Pedagogy Work & 2.4 & 3.1 \\
Collaborative Lesson Planning
\end{tabular}

Table 5. Mean frequency ratings, and SD, on formal learning activities and informal learning factors $(1=$ Never; $2=1$ to 3 times; $3=4$ to 6 times; $4=$ More than 6 times)

Teachers' usefulness ratings ${ }^{2}$ revealed the same pattern (Table 6). Three out of the four informal PD factors were rated as more useful than any of the formal PD activities. A Friedman test showed significant differences among usefulness ratings, $\chi^{2}(7, \mathrm{~N}=37)=16.23, p<.05$. A Wilcoxon test indicated that the factor 'Individual Lesson Planning' was significantly rated as more useful than any of the formal PD activities $(p s<.05)$. Note that this analysis was conducted only with data from those teachers who participated in all types of PD activities $(n=37)$, hence the results refer to a smaller subset of the sample $(38 \%)$. Nevertheless, if we consider $100 \%$ of the sample (see Table 2 and 3), the percentage of teachers rating each learning activity supports the above-mentioned findings. Formal PD activities were rated as moderately useful by most of the teachers who participated in each specific activity, and as highly useful only by $18.3 \%$ to $37.5 \%$ of the sample (see Table 2 ). In contrast, informal PD activities related to the factors 'Individual Lesson Planning', 'Collaborative Pedagogy Work', and 'Collaborative Lesson Planning' were rated as highly useful by a larger percentage of teachers, ranging from $42.6 \%$ to $58.1 \%$; $36 \%$ to $47.9 \%$; and $39 \%$ to $49.5 \%$, respectively.

\footnotetext{
${ }^{2}$ Participants who never participated in a specific activity were not included in this analysis. Formal PD activities that were rated as 1 (Never) by more than $50 \%$ of the participants were not included in the analyses.
} 


\begin{tabular}{|c|c|c|c|c|}
\hline & $\begin{array}{c}\text { Correlation } \\
\text { Usefulness-Frequency }\end{array}$ & Mean & $\mathbf{n}$ & $\begin{array}{l}\text { Standard } \\
\text { Deviation }\end{array}$ \\
\hline \multicolumn{5}{|l|}{ Formal learning activities } \\
\hline Short seminars, lectures, and/or workshops (less than 3 hours) & $.276^{* *}$ & 3.2 & 87 & .65 \\
\hline Long seminars, lectures, and/or workshops (more than 3 hours) & $.294^{* *}$ & 3.3 & 80 & .58 \\
\hline Conferences, symposiums or conventions & .172 & 3.0 & 60 & .53 \\
\hline $\begin{array}{l}\text { Mentoring and/or peer observation and coaching, as part of a } \\
\text { formal school initiative }\end{array}$ & $.380^{* *}$ & 3.0 & 62 & .68 \\
\hline \multicolumn{5}{|l|}{ Informal Learning factors } \\
\hline Collaborative Pedagogy Work & $.477^{* *}$ & 3.2 & 97 & .52 \\
\hline Individual Pedagogy Work & $.273^{* *}$ & 3.0 & 88 & .54 \\
\hline Collaborative Lesson Planning & $.531^{* *}$ & 3.2 & 91 & .56 \\
\hline Individual Lesson Planning & $.674^{* *}$ & 3.3 & 97 & .55 \\
\hline
\end{tabular}

**Correlation is significant at the 0.01 level (2-tailed).

Table 6. Spearman's rho correlations, mean usefulness ratings, and SD, on formal learning activities and informal learning factors $(1=$ None; 2 = Small; 3 = Moderate; 4 = High $)$

Finally, we performed non-parametric correlation analyses between frequency and usefulness for formal PD activities and informal PD factors. The analyses revealed a small correlation for two formal PD activities ('Short seminars, lectures, and/or workshops', and 'Long seminars, lectures, and/or workshops') and one informal PD factor ('Individual Pedagogy Work'). The analyses also showed a moderate correlation for one formal PD activity ('Mentoring and/or peer observation') and one informal PD factors ('Collaborative Pedagogy Work'). Finally, we found a large correlation for two informal PD factors, namely, 'Collaborative Lesson Planning' and 'Individual Lesson Planning'.

\section{Engagement in PD and self-efficacy beliefs}

To explore the relationship between teachers' engagement in PD and their self-efficacy beliefs, we performed Spearman's non-parametric correlations between formal and informal PD and the scores drawn from the three TSES subscales. Based on Richter et al. (2011), we expected that younger and less experienced teachers might rely on collaborative PD activities comparatively more than older and more experienced teachers. For this reason, we included the variables 'Years of Teaching Experience' and 'Age' in the analysis.

Table 7 reports the correlations for formal PD activities and informal PD factors for which the percentage of teachers who ever participated in them was higher than $50 \%$ of the sample. The analysis showed that teachers' self-efficacy ratings were positively related to frequency of two informal PD factors, 'Collaborative Pedagogy Work' and 'Individual Pedagogy Work'. In contrast, no correlation was found for formal PD activities. Notice that neither 'Years of Teaching Experience' nor 'Age' were related to any of the informal PD factors involving collaboration with colleagues. 


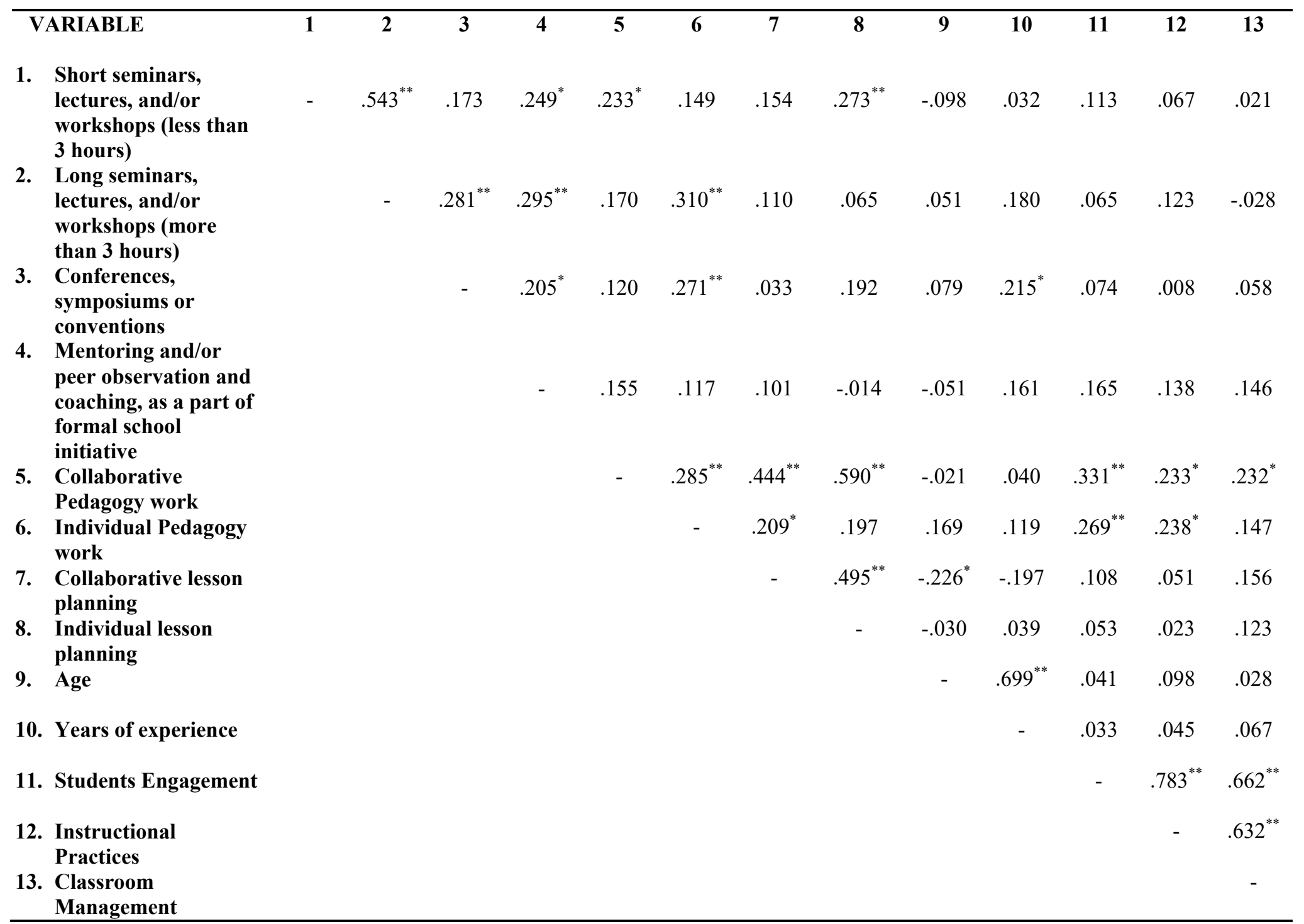

*Correlation is significant at the 0.05 level (2-tailed).

**Correlation is significant at the 0.01 level (2-tailed).

Table 7. Spearman's rho correlations, teachers' engagement in learning activities and teachers' self-efficacy beliefs 
Regression analyses were performed to further explore whether participation in informal PD predicted teachers' self-efficacy. TSES scores for the three subscales (i.e., instructional practices, classroom management, and students engagement) were the dependent variables, whereas informal PD factors were entered as predictors. When self-efficacy in students engagement was predicted, it was found that 'Collaborative Pedagogy Work' was a significant predictor $($ Beta $=0.40, \mathrm{p}<.01)$. The overall model fit was $\mathrm{r}^{2}=0.17$. 'Collaborative Pedagogy Work' also predicted self-efficacy in instructional practices (Beta $=0.45, \mathrm{p}<.01$ ), for which the overall model fit was $r^{2}=0.12$.

\section{DISCUSSION AND CONCLUSIONS}

In response to the first goal, our findings showed that a) Singapore preschool teachers engaged in informal PD - including both collaborative and independent activities - more frequently than in formal PD; b) There were positive correlations between frequency of participation and teachers' perceived usefulness for both formal and informal PD; and c) The correlation between frequency and usefulness was much stronger for informal PD. Next we elaborate on these findings in more detail.

First, we found that teachers partake in 'Individual Lesson Planning' and 'Collaborative Pedagogy Work' significantly more often than in any of the formal PD activities included in our survey. We acknowledge that this result is not surprising. As described in the Introduction, formal PD requires the existence of external providers who design, implement and evaluate the PD (Richter et al., 2011). Indeed, participating in formal PD strongly depends on the availability of these kinds of opportunities. Despite ECDA's active role in conducting a plethora of formal PD initiatives (e.g., workshops, courses, seminars, online modules) (ECDA, 2016), our data suggest that work-embedded learning plays a much more central role in Singapore preschool teachers' professional lives (Bautista, Ng, Múñez, \& Bull, 2016).

It is noteworthy that we did not find differences between teachers' engagement in 'Individual Lesson Planning' and 'Collaborative Pedagogy Work'. Recall that the factor 'Individual Lesson Planning' involved tasks that are deeply embedded in teachers' daily routines (e.g., preparing lessons, construct lesson materials, experiment with new teaching methods, adapt ways of teaching to pupils' needs). These are, according to Eraut (2004), crucial learning activities that are often taken for granted or not even recognized as learning (i.e., invisible learning). In contrast, the activities included under the factor 'Collaborative Pedagogy Work' (i.e., support colleagues in teaching problems, talk about teaching problems with colleagues) emerge from the immediate needs and interests of fellow colleagues and go beyond an individual teacher's basic requirements (Doppenberg, den Brok, \& Bakx, 2013). These kinds of collaborative PD activities involve high levels of interdependency and collective autonomy. These findings provide insights on the high frequency of both individual and collaborative PD activities in Singapore preschools. However, the extent to which teachers are provided with organizational support -in terms of time, space, and resources- is unknown. Further research should be conducted to investigate this issue.

We also identified positive correlations between frequency of participation and teachers' perceived usefulness, in both formal and informal PD. Interestingly, however, the correlation was stronger for informal PD, in particular for the two factors discussed above: 'Individual 
Lesson Planning' and 'Collaborative Pedagogy Work'. These results are consistent with prior PD literature (Ingvarson et al., 2005). There is evidence that teachers often find it hard to apply the knowledge that they acquire in formal PD. As the content covered in these kinds of structured events (e.g., courses, workshops) tends to be too theoretical and abstract, such events are often disconnected from what actually takes place in the classroom (Wagner \& French, 2010). The usefulness of acquiring such knowledge, therefore, seems to be seen by teachers as comparatively lower. In contrast, informal PD activities allow teachers a faster and more effective application or transfer of knowledge, which often emerges from real teaching and learning situations (Nir \& Bogler, 2008). For example, teachers may share information about the content of the lessons that they teach and about students' progress and most common challenges, making sure that all faculty is on the same page with regards to student learning. Teachers may also ask their peers for tips and receive immediate support in response to ad-hoc problematic situations. Preschool teachers in Singapore seem to value the easy accessibility to workplace learning and its situated nature, as discussed in prior studies (e.g., Eraut, 2004). These features seem to make learning more authentic and responsive to teachers' motivations and needs, leading to more meaningful and transformative changes (Hoekstra et al., 2007).

In response to our second goal, we found that teachers' self-efficacy ratings were positively correlated to the frequency of two informal PD factors, 'Collaborative Pedagogy Work' and 'Individual Pedagogy Work'. Additionally, we found that the informal PD factor 'Collaborative Pedagogy Work' predicted teachers' self-efficacy beliefs regarding instructional strategies and student engagement. In a nutshell, it seems that having opportunities to continue to learn informally about pedagogy within the workplace, both individually and especially in collaboration with others, contributes to enhance Singapore preschool teachers' perceived competencies regarding their ability to successfully teach students and motivate them. The lack of relationship between informal PD and classroom management self-efficacy beliefs might be due to the fact that preschool teachers in Singapore rarely encounter challenges related to discipline or disruptive behaviors in the classroom (Lim \& Torr, 2008).

These results are consistent with the study conducted by Guo et al. (2011), who examined how the teaching environment and classroom characteristics predicted the self-efficacy beliefs of 48 preschool teachers from the USA. The authors found that when teachers worked in preschools that fostered high levels of staff sharing and collaboration, teachers tended to exhibit higher levels of self-efficacy, which was in turn associated to higher levels of children's motivation and engagement. Our results are also aligned with Epstein and Willhite (2015), who suggested that teacher learning activities that involve 'joint work' result in better outcomes compared to other types of activities, as well as with Friedman (2000), who found that teachers' feeling of professional isolation was a threat to their self-efficacy beliefs.

In contrast, no correlation was found between formal PD activities and teachers' selfefficacy beliefs. This result was rather surprising, as formal PD in Singapore is carefully designed to further develop teachers' professional knowledge, competence and dispositions (ECDA, 2016). This lack of relationship suggests that formal PD, despite being perceived as relatively useful by preschool teachers, might also be perceived as being somewhat disconnected from the actual reality of the classroom. Contributing to this sense of disconnection might be that formal PD activities in Singapore are generally conducted outside the workplace (e.g., ECDA, tertiary institutions), and are led by external PD providers who 
might be not aware of the specific challenges and problems faced by teachers in their respective centers (Bautista, Wong et al., 2015). The fact that formal PD is often mandatory and planned following a top-down approach - not necessarily in response to teachers' motivations, interests, and needs - might be contributing to the lack of impact on teachers' self-efficacy beliefs (Desimone \& Garet, 2015).

\section{Implications}

This study provides insights that may inform policy and practice concerning the design and implementation of PD initiatives that better meet the needs and preferences of preschool teachers, both in Singapore and in countries with similar characteristics. One of the main takeaways is that despite the emphasis on and resources for formal PD by governments and regulatory agencies, this is not necessarily the most transformative form of learning as perceived by teachers (Darling-Hammond, Chung Wei, \& Andree, 2010). Singapore preschool teachers do consider certain types of formal PD useful, but significantly less useful than other forms of informal learning that are less costly. Work-embedded learning, both collaborative and individual, is more highly valued and has a stronger impact on teachers' perceived competence as preschool educators. More specifically, learning activities that involve sharing pedagogical knowledge with colleagues (e.g., teaching skills, new educational approaches, raising concerns about teaching problems) seem to be the most impactful.

The takeaway for policymakers and school leaders, therefore, is the importance of providing preschool teachers with time and spaces to engage in these kinds of PD activities. To this end, future policies might consider more flexible working schedules and physical layouts that facilitate both sustained teacher collaboration and individual learning. Finally, in order to enhance the impact and responsiveness of PD, we suggest that formal PD should be integrated as part of the informal PD activities in which teachers regularly engage. In line with current discourses in the field of teacher PD (Bautista \& Ortega-Ruíz, 2015), we consider that a better integration will lead to more competent, motivated and satisfied ECE professionals, which in turn will benefit the learning and development of young children.

\section{Limitations and Further Research}

This study is not exempt of limitations. Firstly, it would be desirable to conduct studies with a larger sample size in order to establish more fine-grained comparisons among teachers with different socio-demographic profiles (e.g., age, years of teaching experience, educational background), as well as to explore the impact of PD on additional variables (e.g., job satisfaction). In addition, our data was collected at one time point, which limited our ability to explore causal relationships between engagement in PD and self-efficacy. This issue could be addressed in future studies by collecting data at different time points. Secondly, because the results were from a single source of data (i.e., survey), further studies based on other data sources (e.g., interviews, focus group discussions) should be conducted to provide additional support for our findings. Thirdly, we have focused on teachers' own perceptions regarding usefulness of PD and self-efficacy. It would be relevant to compare the effects of different PD initiatives with different content and design features, both formal and informal, on teachers' actual classroom practices. Finally, this study focuses on preschool teachers from a single country, Singapore, where a plethora of PD initiatives have been implemented in recent years 
(ECDA, 2013, 2016). We encourage researchers from other nations to investigate whether the differences described are also observed among other samples of preschool teachers.

\section{References}

Bandura, A. (1977). Self-efficacy: Toward a unifying theory of behavioral change. Psychological Review, 84(2), 191-215.

Bautista, A., Cañadas, M. C., Brizuela, M. B., \& Schliemann, A. D. (2015). Examining how teachers use graphs to teach mathematics in a professional development program. Journal of Education and Training Studies, 3(2), 91-106.

Bautista, A., Ng, S.-C., Múñez, D., \& Bull, R. (2016). Learning areas for holistic education: Kindergarten teachers' curriculum priorities, professional development needs, and beliefs. International Journal of Child Care and Education Policy, 10(8), 1-18. doi: 10.1186/s40723-016-0024-4.

Bautista, A., \& Ortega-Ruíz, R. (2015). Teacher professional development: International perspectives and approaches. Psychology, Society and Education, 7(3), 240-251.

Bautista, A., Wong, J., \& Gopinathan, S. (2015). Teacher professional development in Singapore: Depicting the landscape. Psychology, Society and Education, 7(3), 311-326.

Borko, H. (2004). Professional development and teacher learning: Mapping the terrain. Educational Researcher, 33(8), 3-15.

Darling-Hammond, L., Chung Wei, R., \& Andree, A. (2010). How high-achieving countries develop great teachers. Stanford Center for Opportunity Policy in Education $\sim$ Research Brief, 1-8.

Desimone, L. M., \& Garet, M. S. (2015). Best practices in teachers' professional development in the United States. Psychology, Society and Education, 7(3), 252-263.

Doppenberg, J. J., den Brok, P. J., \& Bakx, A. W. E. A. (2013). Relationships between primary school teachers' perceived learning outcomes of collaboration, foci and learning activities. Learning and Individual Differences, 28, 1-8.

Duran, E., Ballone-Duran, L., Haney, J., \& Beltyukova, S. (2009). The Impact of a professional development program integrating informal science education on early childhood teachers' self-efficacy and beliefs about inquiry-based science teaching. Journal of elementary science education, 21(4), 53-70.

Early Childhood Development Agency (ECDA) (2013). Enhancing child care quality through continuing professional development. Retrieved from https://www.ecda.gov.sg/PressReleases/Pages/Enhancing-child-care-quality-throughcontinuing-professional-development.aspx

Early Childhood Development Agency (ECDA) (2016). Prospectus 2016. Retrieved from https://www.ecda.gov.sg/Pages/Continuing-Professional-Development.aspx

Epstein, A., \& Willhite, G. L. (2015). Teacher efficacy in an early childhood professional development school. International Electronic Journal of Elementary Education, 7(2), 189-198.

Eraut, M. (2004). Informal learning in the workplace. Studies in Continuing Education, 26(2), 247-273. 
Friedman, I. A. (2000). Burnout in teachers: Shattered dreams of impeccable professional performance. Journal of Clinical Psychology, 56(5), 595-606.

Guo, Y., Dynia, J. M., Pelatti, C. Y., \& Justice, L. M. (2014). Self-efficacy of early childhood special education teachers: Links to classroom quality and children's learning for children with language impairment. Teaching and Teacher Education, 39, 12-21.

Guo, Y., Justice, L. M., Sawyer, B., \& Tompkins, V. (2011). Exploring factors related to preschool teachers' self-efficacy. Teaching and Teacher Education, 27(5), 961-968.

Hoekstra, A., Beijaard, D., Brekelmans, M., \& Korthagen, F. (2007). Experienced Teachers' Informal Learning from Classroom Teaching. Teachers and Teaching: theory and practice, 13(2), 191-208.

Ingvarson, L., Meiers, M., \& Beavis, A. (2005). Factors affecting the impact of professional development programs on teachers' knowledge, practice, student outcomes \& efficacy. Education Policy Analysis Archives, 13(10).

Jones, W. J., \& Dexter, S. (2014). How teachers learn: the roles of formal, informal, and independent learning. Educational Technology Research \& Development, 62(3), 367384.

Klassen, R. M, Tze, V. M. C., Betts, S. M., \& Gordon, K. A. (2011). Teacher Efficacy Research 1998-2009: Signs of Progress or Unfulfilled Promise? Educational Psychology Review, 23(1), 21-43.

Kwakman, K. (2003). Factors affecting teachers' participation in professional learning activities. Teaching and Teacher Education, 19(2), 149-170.

Lim, C., \& Torr, J. (2008). Teaching literacy in English language in Singaporean preschools: Exploring teachers' beliefs about what works best. Contemporary Issues in Early Childhood, 9(2), 95?106.

Lohman, M. C. (2009). A survey of factors influencing the engagement of information technology professionals in informal learning activities. Information Technology, Learning and Performance Journal, 25(1), 43-63.

Moor, H., Halsey, K., Jones, M., Martin, K., Stott, A., Brown, C., . . National Foundation for Educational, R. (2005). Professional development for teachers early in their careers: An evaluation of the early professional development pilot scheme. Research Report RR613 (1-8447-8390-1).

Retrieved

from https://login.libproxy.nie.edu.sg/login?url=http://search.ebscohost.com/login.aspx?direct $=$ true $\& \mathrm{db}=$ eric $\& A N=$ ED502602\&site $=$ ehost-live \&scope $=$ site

Nir, A. E., \& Bogler, R. (2008). The antecedents of teacher satisfaction with professional development programs. Teaching and Teacher Education, 24(2), 377-386.

Pineda, P., Ucar, X., Moreno, V., \& Belvis, E. (2011). Evaluation of teachers' continuing training in the early childhood education sector in spain. Teacher Development, 15(2), 205-218.

Richter, D., Kunter, M., Klusmann, U., Lüdtke, O., \& Baumert, J. (2011). Professional development across the teaching career: Teachers' uptake of formal and informal learning opportunities. Teaching and Teacher Education, 27(1), 116-126.

Rimm-Kaufman, S. E., \& Sawyer, B. E. (2004). Primary-grade teachers' self-efficacy beliefs, attitudes toward teaching, and discipline and teaching practice priorities in relation to the "responsive classroom" approach. The Elementary School Journal, 104(4), 321-341. 
Ross, J., \& Bruce, C. (2007). Professional development effects on teacher efficacy: Results of randomized field trial. Journal of Educational Research, 101(1), 50-60.

Schneider, A., \& Kipp, K. H. (2015). Professional growth through collaboration between kindergarten and elementary school teachers. Teaching and Teacher Education, 52, 3746.

Sheridan, S. M., Edwards, C. P., Marvin, C. A., \& Knoche, L. L. (2009). Professional development in early childhood programs: Process issues and research needs. Early Education and Development, 20(3), 377-401.

Tschannen-Moran, M., \& Hoy, A. W. (2001). Teacher efficacy: Capturing an elusive construct. Teaching and Teacher Education, 17(7), 783-805.

Wagner, B. D., \& French, L. (2010). Motivation, work satisfaction, and teacher change among early childhood teachers. Journal of Research in Childhood Education, 24(2), 152-171. 